\title{
Analysis of Business Model for MOOC Platform
}

\author{
Miao Shang ${ }^{1, a}$, Chunfei Ju ${ }^{1, b}$ and Jun Yang ${ }^{1, c}$ \\ ${ }^{1}$ Mechanical and electrical technology department, Xijing University, Xi'an, China \\ a445700839@qq.com, b344062195@qq.com, '4143433095@qq.com
}

Keywords: MOOC platform; Business model; Economic benefit; Higher education; MOOC course;

\begin{abstract}
In recent years, the MOOC as a kind of new class that has gained rapid development with the development of higher education. The development of MOOC impact the traditional teaching mode of higher education. The MOOC platform is continuously advancing in some colleges and universities. The MOOC emerged as a newly emerging things in the field of education. The depth and breadth are very different of MOOC research in different scholars. In this article, the MOOC platform is introduced; The MOOC platform partners are illustrated; the forms of cooperation are discussed for MOOC platform; the rates for the MOOC platform is analyzed. Finally, the development of the MOOC is pointed: The MOOC education theory and education methods need to innovate; The MOOC learning should be more agreeable; The MOOC design should be more reasonable for the cultivation of students' comprehensive ability. The profit pattern of MOOC should be more reasonable.
\end{abstract}

\section{Introduction of MOOC Platform}

The MOOC is a big open online courses. Coursera and Udacity and edX, the three curriculum may provide more students with learning. In February 2013, the national university of Singapore and the United States company Coursera cooperation, in large open network course platform. In May 2014, the Chinese ministry of education love course syllabus and netease launched cooperation with China's independent intellectual property rights of MOOC platform.

Big platform allows learners to register for free. Coursera provides Chinese official platform, so the time of registration can complete Chinese name [1], but in the E-mail address field does not support QQ mailbox, can choose sina or other email to register. Registrant need to read and agree to the terms of platform's terms of service and related standards, will be able to access or participate in chat rooms, newsgroups, bulletin boards, E-mail, website, online communication or other online BBS and Coursera companies and related sites (one or more sites) provides courses and services. Its code of conduct are some of the constraints, the user wants all students to be able to attend Coursera course and must comply with the following code of conduct: to ensure only registered an account; Guarantee completely on their own efforts to complete all assignments, tests and exams (except cooperation tasks); Promise not to help others fraud; Promise not to use any other dishonest way to improve their performance, also does not use any other dishonest way to increase or decrease the scores of others [2]. These terms are in order to ensure the good operation of course. Growth Figure of Moocs as shown in Fig. 1 


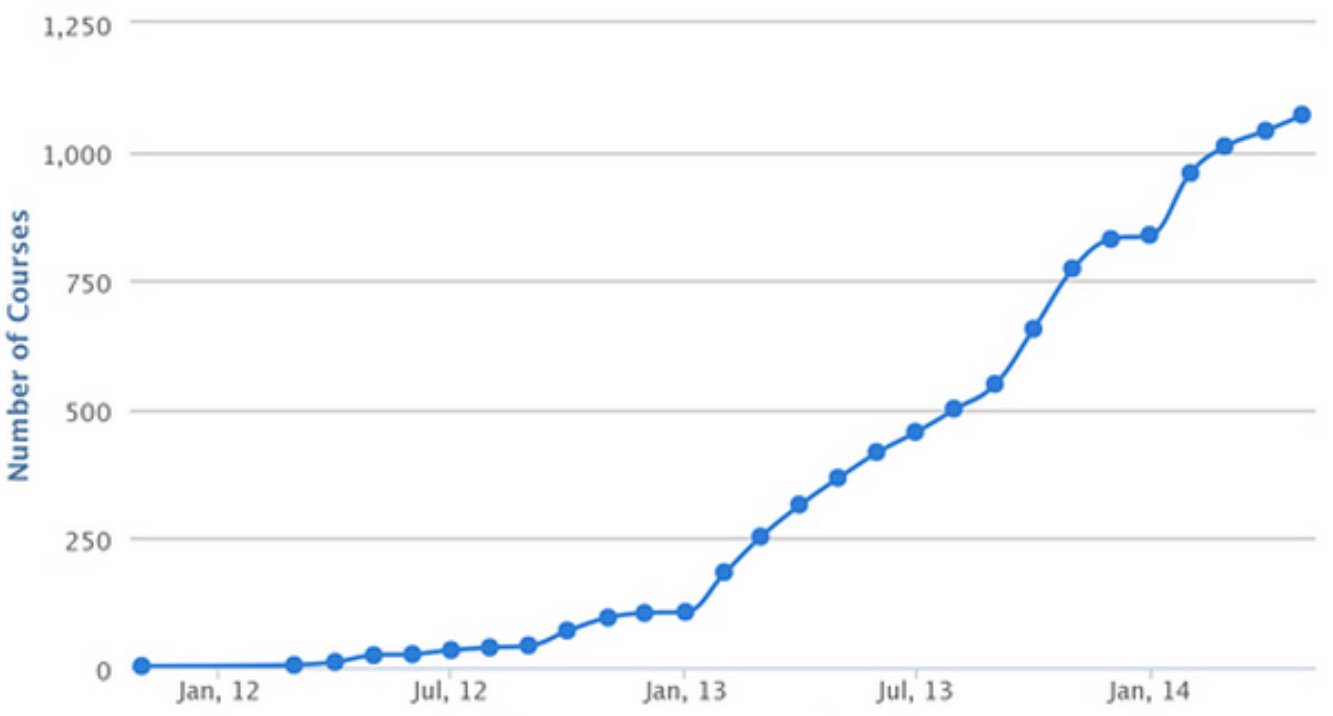

Figure 1. Growth Figure of MOOCS

\section{MOOC Platform Partners}

Coursera in turn education into basic human rights of the goal and many organizations work together from all over the world, there are 108 famous universities all over the world, from all over the world excellent translation companies, non-profit, charitable organization, enterprise, etc [3]. In order to achieve the goal of link the world's best education resources, set up a global Coursera translation cooperation projects, and partners - to select courses complete translated into Arabic, Chinese, has drifted back towards ¥ language, the kazak, Portuguese, Russian, Turkish and Ukrainian, later there will be more languages [4]. In addition, Coursera started Learning center project (Coursera Learning Hubs Initiative), the program will provide students with access to the Internet, and online education resources of physical space. The learning center facilities provide better access to support for online education [5]. The Internet is the most important condition for low cost education, those who cannot access the Internet in the home can students in the learning center Coursera courses, and can interact with local learners learning. Its partners have mainly with new technology and science and technology entrepreneurship as the core theme of Digital October center, focus on entrepreneurship; By the project of communication alumni and hosted by the American embassy personnel to discuss political, diplomatic, economic, energy center in the United States; Headquartered in mumbai, is committed to improve the education system of the Tap the Tech; And development of the enterprise cooperation with state and national government agencies and the community work together to improve the quality of education Learning Links foundation; Focus on professional development for teachers. Mrs Lahm women's college and the bluebells international school and so on, and it has net, shells, etc.

\section{Forms of Cooperation for MOOC Flat}

The three major platforms in running mode difference is not big. They all provide free learning for students. In the aspect of teaching mode, although different platform has its own characteristics, but their courses are made by the teaching video, assignments and test, discussion and answer questions after class of this a few parts. But from the perspective of the organization and cooperation in the way of curriculum, the three major platforms have certain difference [6]. Udadty mainly cooperate with teachers, the teachers' independent production course, such cooperation way makes Udacity courses progress is relatively slow, therefore, Udacity is now cooperating with some universities have to expand influence; EdX platform required to participate in the course strictly follow the construction specification, stay online courses with tighter tuen nuclear processes, with most of the schools is the 
area of the wing chu. EdX will provide paid to help release course of colleges and universities [7]. Coursera choices of university academic rankings of the top schools as the object of cooperation, to provide high-quality free course construction guidance services, to provide online tutoring construction course for cooperation of colleges and universities, colleges and universities with production team to help the teacher complete course. This led to a growing number of colleges and universities to join Coursera cooperation way, and actively introduce the distinctive online courses.

\section{Rates for MOOC Platform}

Since 2012 the Internet company with online courses as the core. Online courses have emerged and have gained rapid development. Public network teaching platform gathered plenty of free, high-quality international school courses [8]. A MOOC is a big open online courses. At present, the development of the MOOC is very rapidly in various countries. On every platform of MOOC in advance.

Edx is a non-profit organization, but from a long-term point of view, will establish a business model. And the non-profit organization Coursera and Udacity platform is has been developing all kinds of business strategy, including information to students to potential employers or advertisers, homework rating, access to social network and BBS, advertising sponsorship form of courses, course fees. The edX business model is a single, only charge professional certification. Coursera and Udacity are trying different business model, but it is unclear which business model can be sustained. Part in Coursera platform as part of online courses need to pay for additional services, the specific price according to the specific conditions for each course business accounting [9]. Udacity platform of course fee is given every month pricing, course in different times and different price. Both platforms support began to class two weeks to apply for a refund [10]. And non-profit professional certification in the edx platform of charge is uncertain, such as MIT of fluid mechanics series courses, students pay 175 dollars in the fall of 2013, in the spring of 2014 students need to pay $\$ 275$, including two professional courses, each project cost $\$ 100$ and $\$ 100$, edx platform also for learners to provide a platform to volunteer course, learners can voluntarily donated a fee for courses, but shall not be less than $\$ 25$.

MOOC storm swept across the world, the development of the MOOC MOOC an upsurge in learning and research. Sydney institute of Sui Fai John Mak according to the different theoretical basis for the MOOC is divided into five categories, namely teaching socialist MOOC, MOOC of cognitivism, constructivism MOOC, social constructivism of MOOC, and associated MOOC [11]. According to the different emphasis of each MOOC course design will be divided into MOOC MOOC based on social network, based on task MOOC and based on the content of MOOC. LisaMXane think all MOOC classification is not good or bad, no comprehensive and one-sided. The purpose of these courses is not so much in the open network environment of distributed learning course content and skills, rather than learn social skills such as communication.

\section{Development Direction of MOOC}

Surging MOOC course and people for the improving of the MOOC interest, MOOC has become a hot topic of higher education magazine articles. MOOC emerged as a newly emerging things in the field of education, different scholars to research the depth and breadth of its are very different. Subsequent development of MOOC still need to consider from the following aspects:

(1) The MOOC education theory and education method requires innovation. Three big platform in the course teaching

Close to the traditional classroom, MOOC itself should have unique teaching mode and teaching method. Such as task driven type, game type, etc.

(2) The MOOC learning should be more cheerful. Higher education in the future how to better serve the society, what

Any type of students, subject, learning environment, learning content in the form of MOOC is effective. MOOC learners' learning motivation and learning performance influence factors what, this will be a MOOC are the important factors of sustainable development. 
(3) The MOOC design should be more reasonable for the cultivation of students' comprehensive ability. In different forms of learning, MOOC also need to help learners to improve learning effect. MOOC can adopt what kind of teaching design or technical support for learners to provide a more effective learning experience are to be further discussed.

(4) The profit pattern of MOOC should be more reasonable. Professor offer free MOOC spend a lot of time and effort, it would be difficult to long-term security courses teaching quality. MOOC development, maintenance, guidance and operation of high costs borne by the who. MOOC need to find a sustainable business model. Such as: the learners in the process of learning can also create some practical value, and then have the ability to pay part of the course fee.

\section{References}

[1] Z. Wang, J. X. Tian: Inheriting Hin for Class in Our Country the Development of the SWOT Analysis, Journal of the new curriculum (below), Vol. 7(2013) No.7.

[2] W. X. Cai, J. Wang: The First Year of MOOC, Vol. 4(2012), P. 16-18.

[3] B. C. Ji: Our Country's Higher Education Scale Forecast Analysis in 2020, Vol. 1 (2011) No. 1, p. 305.

[4] L. Yuan, Stephen Powell, H. L. Ma: International Status Quo Analysis of Massive Open Online Courses Closed, Vol. 84(2013) No.3.

[5] Benoit Minogue: Higher Education Spending and Output-Complexity of Relationship, Peking University Education review, Vol. 2 (2013), 60.

[6] J. B. Wang, H. T. Yang: New Field of Overseas Investment-New Trend of Transnational Higher Education (Dong Yue Review, China, 2012)

[7] H. Y. Liu: U DP Proportion Higher Education and Social Policy Research, Vol. (2012), P. 27-28.

[8] Henry m. levin. Education How to Adapt to Future-Background of American Education, Peking University Education Review, Vol. 2 (2013), p. 2-3.

[9] P. Wang: New Development and Application of Large-Scale Online Open Courses, Vol.19 (2013) No.1.

[10] G. P. Feng: Transnational Education-International Comparative Study (Shanghai People's Publishing House, China ,2010)

[11]T. Wang, Q. Li: MOOC-A Giant Open Courses of Unicom Based Model, Vol. 19(2013)No.3. 